\title{
Aluminium and lead abnormalities in children on haemodialysis: relationship with some medications
}

\author{
Manal F. Elshamaa1 ${ }^{1}$ Samar Sabry², Inas Mokhtar ${ }^{1}$, Gamila S. El-Saaid ${ }^{3}$, Mona Raafat ${ }^{4}$, \\ Dalia A. Abd-El Haleem ${ }^{4}$
}

1Paediatric Department, National Research Centre, Cairo, Egypt

2Paediatric Department, Faculty of Medicine, Cairo University, Egypt

${ }^{3}$ Medical Biochemistry Department, National Research Centre, Cairo, Egypt

${ }^{4}$ Clinical and Chemical Pathology Department, National Research Centre, Cairo, Egypt

Submitted: 20 May 2009

Accepted: 27 August 2009

Arch Med Sci 2010; 6, 3: 420-429

DOI: 10.5114/aoms.2010.14266

Copyright (c) 2010 Termedia \& Banach

\section{Abstract}

Introduction: The determination of toxic elements in the biological samples of human beings is an important clinical procedure. This study was performed to investigate the prevalence of abnormal blood contents of 2 trace elements (TEs), aluminum ( $\mathrm{Al}$ ), and lead $(\mathrm{Pb})$ in hemodialysis (HD) patients and to analyze their relationship with the medications, such as $\mathrm{CaCO}_{3}$, Ca acetate, 1,25-dihydroxy vit. $\mathrm{D}_{3}$, and erythropoietin (EPO), as well as hematocrit level.

Material and methods: We included 43 patients on maintenance HD and they had continued the previously mentioned medications for at least 3 months. None of the patients were on Al containing phosphate binding agents.

Results: Serum aluminum and lead levels were significantly increased than in the healthy controls, but levels of both of them were far below toxic values. Male patients had higher mean levels of lead than did females. A strong positive correlation was found between serum $\mathrm{Al}$ and serum $\mathrm{Pb}$ levels among patients $(r=0.075, p=0.0001)$. The serum level of $\mathrm{Pb}$ was positively correlated with the serum albumin in HD patients $(r=0.45, p=0.03)$. Both serum aluminium and lead levels positively correlated with the EPO dose taken by the patients ( $r=0.77, p=0.0001$ and $r=0.67, p=0.0001$ respectively).

Conclusions: The blood level of trace metals of these HD patients was not related to their medications except for the EPO dose. However, caution must be exercised in interpreting this result as dose and duration of medication may play an important role. Al and $\mathrm{Pb}$ over load may be considered from the causes of inadequate response to epoetin therapy.

Key words: aluminium, lead, medications, haemodialysis.

\section{Introduction}

Despite recent improvements in dialyser design and advances in dialysis technique, many uraemic symptoms remain unresolved by maintenance dialysis. Some of these clinical symptoms are attributed to inadequate dialysis or so-called uraemic toxins. However, the abnormal metabolism of trace elements (TES) in chronic dialysis patients, a frequently overlooked fact, may be one of the contributing factors to the patients' clinical discomforts [1, 2].

Trace metal burden in chronic renal insufficiency and dialysis patients has been studied. Those studies, however, are somewhat incomplete owing to small sample sizes, contradictory results, and different analytic techniques [3].

\author{
Corresponding author: \\ Manal F. Elshamaa, MD \\ Paediatric Department \\ National Research Centre \\ Cairo, Egypt \\ E-mail: \\ manal_elshmaa@hotmail.com
}


Aluminium (Al) is a well known risk factor for increased morbidity and mortality among haemodialysis (HD) patients all over the world [4]. The well-described long-term effects of sustained exposure to aluminium in patients with end-stage renal disease (ESRD) are a result of uptake and storage of aluminium, leading to cellular toxicity. Accumulation of aluminium in the tissues of patients on chronic haemodialysis may cause dysfunction of some organs [5]. In 1976, Aifrey et al. [6] attributed the previously described syndrome of dialysis dementia to an increased aluminium concentration in the brain of their encephalopathic patients. Subsequently, the association between increased aluminium concentrations in the cerebrum and dialysis encephalopathy seems to have been reasonably well established [7]. In 1971, Parsons et al. [8] demonstrated abnormally high aluminium concentrations in the bone of patients on chronic HD. More direct evidence for a causal association between dialysis osteomalacia and aluminium accumulation in bone has been provided by experimental and human studies of bone aluminium concentrations and bone histology [9].

Microcytic hypochromic anaemia has been reported in patients with excessive aluminium accumulation [10]. Serum aluminium concentrations may fluctuate as a result of oral [11] or parenteral $[12,13]$ administration of aluminium-containing compounds. Most of the reports on aluminium toxicity in HD patients have appeared from western countries. Reports from the Arab world on the prevalence of toxicity, or on the measures adopted to contain this, are scanty [14].

Among the general population, it has been assumed that an average of $150 \mathrm{~g}$ to $250 \mathrm{~g}$ of lead $(\mathrm{Pb})$ is ingested through food each day, $5-10 \%$ of which is absorbed [15]. The other sources for lead poisoning may be lead-soldered kettles, cans, and lead-glazed pottery, which release lead when acidic fluids are stored or cooked in them [15]. The lead in blood is equilibrated with that of lead in tissues, including many potential target organs such as the brain and kidney. The kinetic model of lead in the body is not defined well, but usually it consists of two pools: in the blood and in the skeleton, which may be divided further into labile and deep pools [16]. The kidney is the main organ excreting lead from the pool. Thus, lead burdens have a tendency to be accumulated in patients with renal failure [17].

The skeleton acts as a reservoir of lead, and it may be mobilized by physiological and pathological states including pregnancy, lactation, and osteoporosis $[18,19]$. In patients with end stage renal disease (ESRD), hyperparathyroidism, abnormal vitamin D metabolism, and consequent osteoporosis have frequently been observed [20]. Taken together with the lack of renal excretion and stimulated bone resorption, the blood level of lead seems to increase in ESRD and may aggravate uraemic symptoms such as peripheral neuropathy and anaemia.

The classic clinical manifestations of industrial lead poisoning include colic, anaemia, peripheral neuropathy, encephalopathy, renal impairment, hypertension, and reproductive disability [21]. More recently, recognition has become widespread that, in addition to its clinically evident toxicity, lead also causes a spectrum of adverse effects at levels of exposure insufficient to produce obvious signs and symptoms. The premise underlying this recognition is that there exist asymptotic, subclinical counterparts. Thus, clinically obvious manifestations of lead poisoning such as anaemia, peripheral neuropathy, and renal failure lie at the upper end of the range of toxicity, while such covert effects as impaired synthesis of haem, altered excretion of uric acid, and slowed nerve conduction are their subclinical correlates [22]. Although many investigators have described increased blood levels of lead in renal failure patients [23-26], the role of lead on the clinical characteristics remains to be elucidated.

Multiple drugs are frequently used for the underlying diseases and uraemic complications. The possibility of trace metal contamination of various medications and the effect of medications on the metabolism of trace metals are still unknown.

The present study was undertaken to investigate the prevalence and the clinical correlation of aluminium and lead abnormalities among ESRD patients receiving maintenance haemodialysis, and to analyse their relationship with frequently used drugs such as erythropoietin (EPO), Ca carbonate $\left(\mathrm{CaCO}_{3}\right)$, Ca acetate, and Rocaltrol $\left(1,25-(\mathrm{OH})_{2}\right.$ vit. $\left.\mathrm{D}_{3}\right)$.

\section{Material and methods}

Forty-three children with ESRD undergoing haemodialysis, at the haemodialysis unit of the Centre of Paediatric Nephrology and Transplantation (CPNT), Children's Hospital, Cairo University were investigated. The study was conducted from October 2008 to March 2009. Detailed patient characteristics are given in Table I. All patients were dialysed using a polysulfone dialyser, with bicarbonate dialysate, using a blood flow rate of $80-150 \mathrm{ml} / \mathrm{min}$ and a dialysate flow rate of 500 $\mathrm{ml} / \mathrm{min}$. Each subject was dialysed 3 times per week using polysulfone membranes. The dialysate fluids were prepared from concentrated salt solutions and from bicarbonate powder in sealed containers. As recommended by the FDA, the water purification system combines a double softener with a double granular charcoal filter and a double reverse osmosis module in series. The accepted limit for aluminium contamination in the ultrapure water 
Manal F. Elshamaa, Samar Sabry, Inas Mokhtar, Gamila S. El-Saaid, Mona Raafat, Dalia A. Abd-El Haleem

Table I. Comparison of general characteristics between controls and patients with end stage renal disease

\begin{tabular}{|lccc|}
\hline Variable & Controls $(n=43)$ & Patients $(n=43)$ & Value of $p$ \\
\hline Age [years] & $10.5 \pm 3.32$ & $11 \pm 3.36$ & NS \\
\hline Male/female [\%] & $28 / 15(65.12 \% / 34.88 \%)$ & $22 / 21(51.16 \% / 48.84 \%)$ & NS \\
\hline Systolic blood pressure $[\mathrm{mmHg}]$ & $95.44 \pm 9.81$ & $123.18 \pm 14.60$ & $<0.0001^{*}$ \\
\hline Diastolic blood pressure $[\mathrm{mmHg}]$ & $65.67 \pm 10.24$ & $82.73 \pm 12.41$ & $<0.001^{*}$ \\
\hline Antihypertensive medication [\%] & - & $33(76.74 \%)$ & \\
\hline Duration of dialysis [years] & & $2.91 \pm 1.44$ & \\
\hline Dialyser SA (range) & & $0.7-1.3$ & \\
\hline Kt/V & & $1.64 \pm 0.38$ & \\
\hline
\end{tabular}

Data are means $\pm S D$, number (\%) or range as applicable. Significance was estimated using independent $t$-test, ${ }^{*} p$ was significant $<0.01$, $S A$ - surface area, $K t / V$ - adequacy of dialysis

was $0.01 \mathrm{ppm}$. According to the guidelines of the American Association of Medical Instruments [27] and European Pharmacopoeia [28], appropriate laboratory methods were chosen to detect bacteria (upper limit for bacterial growth < 100 colony forming units per millilitre in dialysate) as well as endotoxins (upper limit $0.25 \mathrm{EU} / \mathrm{ml}$ ) and other bacteria-derived substances (whole blood cytokine induction assay). Inclusion criteria included children on regular HD treatment for not less than 4 months, using bicarbonate dialysate and free from apparent acute illness. Patients with severe illness or acute medical events were excluded.

Patients had taken routine medications in a dialysis unit for at least 3 months, such as phosphate-binding agents calcium carbonate (35 patients [81.40\%], 500 mgltab Ca 0.2 g, 10 mEq) at a dose of $500-4000 \mathrm{mg} /$ day, or calcium acetate (8 patients [18.60\%], $500 \mathrm{mg} \backslash \mathrm{tab}, \mathrm{Ca} 0.2 \mathrm{~g}, 10 \mathrm{mEq}$ ) at a dose of 1500-2000 mg/day. Patients with parathormone (PTH) level greater than $100 \mathrm{pg} \backslash \mathrm{ml}$ or hypocalcaemia received daily Rocaltrol (38 patients [88.37\%]), at a dose of 0.25-2 $\mu \mathrm{g} /$ day. Medication compliance was checked by questionnaires and re-enforced at each dialysis unit. An EPO 750-9000 IU/week subcutaneous injection was administered to maintain haematocrit between $28 \%$ and $31 \%$. None of the patients received $\mathrm{Al}$ containing phosphate-binding agents. Forty-three healthy, age- and gender-matched children (28 [65.12\%] male, 15 [34.88\%] female; average age 10.5 \pm 3.32 years, range 3-17 years) (NS) were recruited from the paediatric clinic of the National Research Centre to serve as controls. Written consent was obtained from the parents of each patient.

\section{Clinical and biochemical tests}

All the patients were subjected to full history taking and thorough clinical examination. Haemoglobin ( $\mathrm{Hb})$, haematocrit (HCT), albumin (ALB), serum calcium (Ca), serum phosphorous $(\mathrm{Ph})$, blood urea nitrogen (BUN) and creatinine were measured for all patients using an automatic biochemistry analyser.

\section{Blood sample collection}

A peripheral blood sample was obtained prior to the haemodialysis session from the venous part of the arteriovenous fistula using a specially selected disposable plastic syringe. The specimen was transferred to a plastic tube and then immediate centrifugation was done for $10 \mathrm{~min}$ at 5,000 rpm at $4^{\circ} \mathrm{C}$. The centrifuged serum was transferred into sterile tubes. All samples were stored in a refrigerator at $4^{\circ} \mathrm{C}$ until the time of analysis.

\section{Determination of serum concentration of aluminium and lead}

Trace lead and Al determination was carried out using a graphite furnace Atomic Absorption Spectrometer (Varian Spectr. AA 220) equipped with a graphite furnace auto-sampler (GTA-110). The spectral lines used for $\mathrm{Pb}$ and $\mathrm{Al}$ determination were $283.3 \mathrm{~nm}$ and $396.2 \mathrm{~nm}$ respectively. Background correction was carried out using a deuterium arc lamp.

Before $\mathrm{Pb}$ measurement, samples were diluted five times with a mixture of Triton X-100 (0.2\%) and Dow Corning Antifoam B (0.2\%) then a portion of the sample was introduced into the graphite atomization tube. For Al measurements, samples were diluted $1: 1$ with a mixture of Triton X-100 $(0.2 \%)$ and Dow Corning Antifoam B (0.2\%) then a portion of the sample was atomized.

For both elements the standard addition technique was applied to construct the analytical calibration curve in which an increasing volume of $\mathrm{Pb}$ or Al solution was added to the sample to give similar atomization behaviour of both samples and standards. A volume of the standard solution $(100 \mu \mathrm{g} / \mathrm{l}$ for $\mathrm{Pb}$ and $20 \mu \mathrm{g} / \mathrm{l}$ for $\mathrm{Al})$ was added to give final concentrations of the added lead of 
10, 20, 30 and $40 \mu \mathrm{g} / \mathrm{l}$ and $\mathrm{Al}$ of 2,4 and $8 \mu \mathrm{g} / \mathrm{l}$ respectively. Palladium solution $(1000 \mu \mathrm{g} / \mathrm{ml})$ was used as a matrix modifier from which a volume of $10 \mu \mathrm{l}$ was added before every sample or standard measurement of $\mathrm{Pb}$. A portion of sample $(20 \mu \mathrm{l})$ was added to the atomization tube then the heating programme started. The calibration curve was found to be linear over the used calibration range. The temperature programme used for atomization included maximum drying temperatures of $120^{\circ} \mathrm{C}$, ashing temperatures of $480^{\circ} \mathrm{C}$ and $1100^{\circ} \mathrm{C}$, and atomization temperatures of $2500^{\circ} \mathrm{C}$ and $2500^{\circ} \mathrm{C}$ for $\mathrm{Pb}$ and $\mathrm{Al}$ respectively [29].

\section{Determination of intact parathyroid hormone in serum by chemiluminescent immunometric assay}

IMMULITE/IMMULITE 1000 is a solid phase chemiluminescent immunometric assay (supplied by SIEMENS Medical Solution Diagnostics) [30].

\section{Statistical analysis}

Statistical Package for the Social Sciences (SPSS) version 11.0 was used for analysis of data. Matching was done by using two main approaches: pair (individual) matching and frequency matching. Data were summarized as mean \pm SD, range or percentage. Comparisons of continuous variables between the two groups were performed by independent-samples $t$ test where appropriate. Pearson's analysis was performed to correlate the serum concentration of aluminium and lead with the individual variables. Multiple linear regression analysis with backward method was performed to determine the contribution of various factors as independent variables or covariates to aluminium or lead as the dependent variables. A $p$ value of $<0.05$ was considered significant.

\section{Results}

\section{Comparison of general characteristics between controls and patients with end stage renal disease}

There were significant differences in systolic (123.18 $\pm 14.60 \mathrm{mmHg}$ vs. $95.44 \pm 9.81 \mathrm{mmHg}, p<0.0001)$ and diastolic blood pressures $(82.73 \pm 12.41 \mathrm{mmHg}$ vs. 61.65 $\pm 10.24 \mathrm{mmHg}, p<0.001$ ) between the HD patients and the controls. Thirty-three patients have had antihypertensive medication Table I.

\section{Comparison of basic biochemical data between controls and patients with end stage renal disease}

Moderate anaemia was present in the haemodialysis patients when compared to the controls (Table II). Haemoglobin was $9.72 \pm 1.47$ $\mathrm{mg} / \mathrm{dl}$ vs. $14.23 \pm 1.50 \mathrm{mg} / \mathrm{dl}$ in the controls ( $p<0.001)$. Serum calcium was significantly lower in the patients than in the controls $(10.27 \pm 1.68$ $\mathrm{mg} / \mathrm{dl}$ vs. $10.91 \pm 0.40 \mathrm{mg} / \mathrm{dl})$, and hyperphosphataemia ( $5.04 \pm 3.42 \mathrm{mg} / \mathrm{dl}$ vs. $3.9 \pm 0.58 \mathrm{mg} / \mathrm{dl}$ ) was present in the HD patients. There was a significant statistical difference between the HD patients and the controls as regards the parathormone (PTH) level (140.62 $\pm 90.32 \mathrm{pg} / \mathrm{ml}$ vs. $1.65 \pm 0.65 \mathrm{pg} / \mathrm{ml}, p<0.0001)$.

Serum aluminium levels were significantly higher in the ESRD patients than in the healthy controls $(18.43 \pm 4.37 \mu \mathrm{g} / \mathrm{l}$ vs. $6.50 \pm 1.60 \mu \mathrm{g} / \mathrm{l}, p<0.001)$ (Figure 1). The ESRD patients had higher blood lead levels than in the controls $(34.31 \pm 9.70 \mu \mathrm{g} / \mathrm{l}$ vs. 5.36 $\pm 1.77 \mu \mathrm{g} / \mathrm{l}, p<0.0001$ ) (Figure 2).

The blood levels of both aluminium and lead were far below their toxic values (>100 $\mu \mathrm{g} / \mathrm{l}$ for Al level, and > $60 \mu \mathrm{g} /$ l for lead level) [31]. Male patients had higher mean levels of lead than did females (38.50 $\pm 7.61 \mu \mathrm{g} / \mathrm{l}$ vs. $30.13 \pm 10.05 \mu \mathrm{g} / \mathrm{l}, p<0.04)$ (Table III). There were no statistical differences between males and females with regard to age or dialysis duration.

\section{Correlation between aluminium and lead levels among haemodialysis patients}

A strong positive correlation was found between serum $\mathrm{Al}$ and serum $\mathrm{Pb}$ levels among the $\mathrm{HD}$ patients $(r=0.075, p=0.0001)$ (Table IV).

Correlation of aluminium and lead levels with different variables in haemodialysis patients

A positive linear correlation was revealed between the serum lead levels and the age of HD patients

Table II. Comparison of basic biochemical data between controls and patients with end stage renal disease

\begin{tabular}{|lccc|}
\hline Variable & Controls & Patients & Value of $p$ \\
\hline Haemoglobin $[\mathrm{mg} / \mathrm{dl}]$ & $14.23 \pm 1.50$ & $9.72 \pm 1.47$ & $<0.001^{\star \star}$ \\
\hline Serum calcium $[\mathrm{mg} / \mathrm{dl}]$ & $10.91 \pm 0.40$ & $10.27 \pm 1.68$ & $<0.05^{\star}$ \\
\hline Serum phosphorous $[\mathrm{mg} / \mathrm{dl}]$ & $3.90 \pm 0.58$ & $5.04 \pm 3.42$ & $<0.001^{\star \star}$ \\
\hline Serum parathormone $[\mathrm{pg} / \mathrm{ml}]$ & $1.65 \pm 0.65$ & $140.62 \pm 90.32$ & $<0.0001^{\text {** }}$ \\
\hline
\end{tabular}

Data are reported as means $\pm S D$. Significance was estimated using independent $t$-test, ${ }^{*} p$ was significant if $<0.05$ or ${ }^{* *} p<0.01$ 


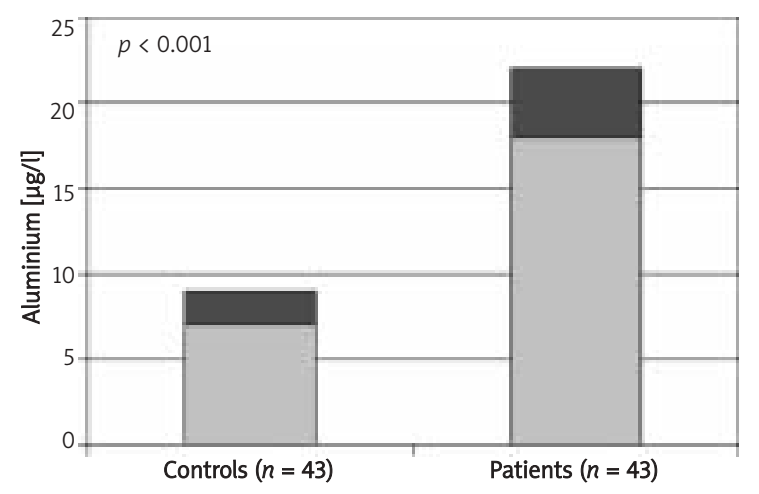

Figure 1. Comparision of the serum aluminium levels between haemodialysis patients and healthy controls. Columns represent mean \pm SD

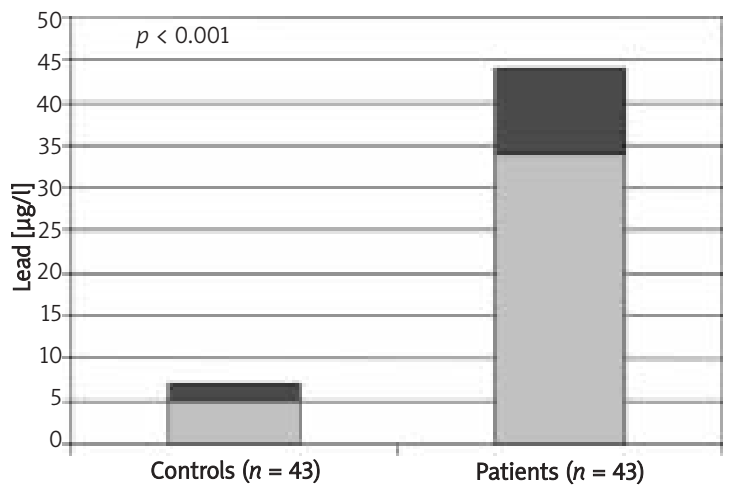

Figure 2. Comparision of the serum lead levels between haemodialysis patients and healthy controls. Columns represent mean \pm SD

Table III. Comparison of clinical characteristics and serum aluminium and lead levels between male and female patients with end stage renal disease

\begin{tabular}{|lccc|}
\hline Variable & Male & Female & Value of $p$ \\
\hline No. & 22 & 21 & NS \\
\hline Age [years] & $11.95 \pm 3.65$ & $10.04 \pm 2.91$ & NS \\
\hline Dialysis duration [years] & $3.31 \pm 1.51$ & $2.51 \pm 1.31$ & NS \\
\hline Aluminium $[\mu \mathrm{g} / \mathrm{l}]$ & $19.05 \pm 5.29$ & $17.80 \pm 3.35$ & NS \\
\hline Lead $[\mu \mathrm{g} / \mathrm{l}]$ & $38.50 \pm 7.61$ & $30.13 \pm 10.05$ & $<0.04^{*}$ \\
\hline
\end{tabular}

Data are reported as means $\pm S D$. Significance was estimated using independent $t$-test, ${ }^{*} p$ was significant if $<0.05$

Table IV. Correlation between serum aluminium and lead levels among HD patients

\begin{tabular}{|lcc|}
\hline \multicolumn{3}{|c|}{ Aluminium } \\
\hline & $r$ & Value of $p$ \\
\hline Lead & 0.75 & $0.0001^{\star}$ \\
\hline
\end{tabular}

Correlation was performed by Pearson's analysis. Significant * $p<0.01$

( $r=0.50, p=0.003)$, but not between the serum levels and the dialysis duration ( $r=0.29, p=\mathrm{NS})$. Another positive finding was that serum lead levels increased with increasing dialyser surface area $(r=0.54, p=0.01)$. A positive correlation was found between the serum lead levels and the serum albumin in HD patients $(r=0.45, p=0.03)$. Serum parathyroid hormone level correlated positively with the serum aluminium (Figure 3) and the serum lead levels (Figure 4) among HD patients $(r=0.78$, $p=0.0001$, and $r=0.60, p=0.0001$, respectively), but was not correlated with the age or with the dialysis duration. A significant positive correlation was revealed between the serum aluminium levels and the EPO dose taken by the patients ( $r=0.77$, $p=0.0001$ ) (Figure 5). Also the serum level of lead was correlated positively with the EPO dose received by the patients $(r=0.67, p=0.0001$ ) (Figure 6, Table V).
Multiple linear regression analysis comparing the correlation of aluminium and lead levels with individual variables in serum of haemodialysis patients

On correlating the Al and lead values and other individual variables by multiple linear regression analysis, PTH and EPO dosage were variables that were independently associated with elevated Al values $(p<0.05)$. Serum concentration of lead was independently associated with age, PTH level and EPO dosage taken by the patients $(p<0.05)$ (Table VI).

There were statistical correlations between the erythropoietin dose used and the haemoglobin value, and haematocrit level in these patients $(r=0.45$, $p=0.03$, and $r=0.47, p=0.02$, respectively).

\section{Discussion}

The behaviour of trace elements received scarce attention until the 1970s, when dialysis dementia was found to be closely related to a rise in aluminium concentration $[2,7,13]$. Contaminated water and aluminium-containing antacids or phosphate binders were two important sources of aluminium accumulation in these patients [32]. Some kinetic studies showed the release of some 
Table V. Correlation of serum aluminium and lead levels with different variables in HD patients

\begin{tabular}{|lcccc|}
\hline Variable & \multicolumn{2}{c}{ Aluminium } & \multicolumn{2}{c|}{ Lead } \\
\cline { 2 - 5 } & $r$ & Value of $p$ & $r$ & Value of $p$ \\
\hline Age & 0.23 & NS & 0.50 & $0.003^{* *}$ \\
\hline Dialysis duration & -0.07 & NS & 0.29 & NS \\
\hline Dialyser SA & 0.28 & NS & 0.54 & $0.01^{*}$ \\
\hline Kt/V & 0.09 & NS & -0.23 & NS \\
\hline Haemoglobin & 0.01 & NS & -0.57 & NS \\
\hline Haematocrit [\%] & 0.02 & NS & -0.05 & NS \\
\hline Albumin & 0.11 & NS & 0.45 & $0.03^{*}$ \\
\hline Serum calcium & -0.003 & NS & -0.01 & NS \\
\hline Serum phosphorous & -0.16 & NS & 0.03 & NS \\
\hline Serum parathormone & 0.78 & $0.0001^{* *}$ & 0.60 & $0.0001^{* *}$ \\
\hline EPO dosage & 0.77 & $0.0001^{*}$ & 0.67 & $0.0001^{*}$ \\
\hline
\end{tabular}

Correlation was performed by Pearson's analysis. Significant $p<0.05$ or ${ }^{* *} p<0.01$

Table VI. Multiple linear regression analysis comparing the correlation of Al and lead levels with individual variables in serum of haemodialysis patients

\begin{tabular}{|lcc|}
\hline Variables & $\beta$ & Value of $p$ \\
\hline Dependent variables, Al & & \\
\hline Age & 0.01 & $\mathrm{NS}$ \\
\hline Haemoglobin & 0.04 & $\mathrm{NS}$ \\
\hline Parathormone & 0.34 & $0.05^{*}$ \\
\hline EPO dosage & 0.45 & $0.03^{*}$ \\
\hline Dependent variables, Pb & & \\
\hline Age & 0.56 & $0.007^{*}$ \\
\hline Haemoglobin & -0.01 & $\mathrm{NS}$ \\
\hline Parathormone & 0.35 & $0.05^{*}$ \\
\hline EPO dosage & 0.45 & $0.04^{\star}$ \\
\hline
\end{tabular}

${ }^{*} p<0.05$ was considered significant

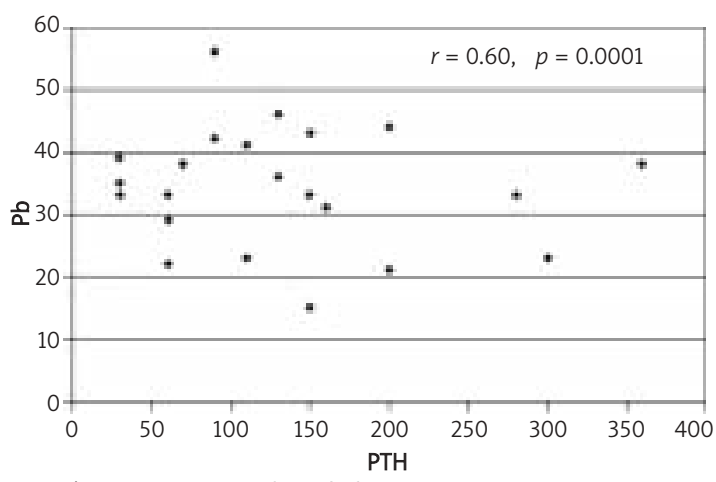

Figure 4. Scatter plot of Pb vs. PTH

trace elements, from disposable dialysis coils and Kiil dialysers [33-35]. Of these investigations, some claimed that patients could accumulate or deplete those trace elements from dialysis fluid through

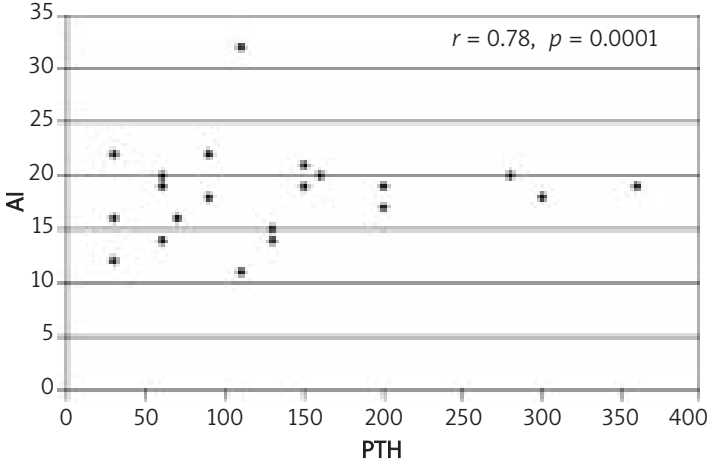

Figure 3. Scatter plot of Al vs. PTH

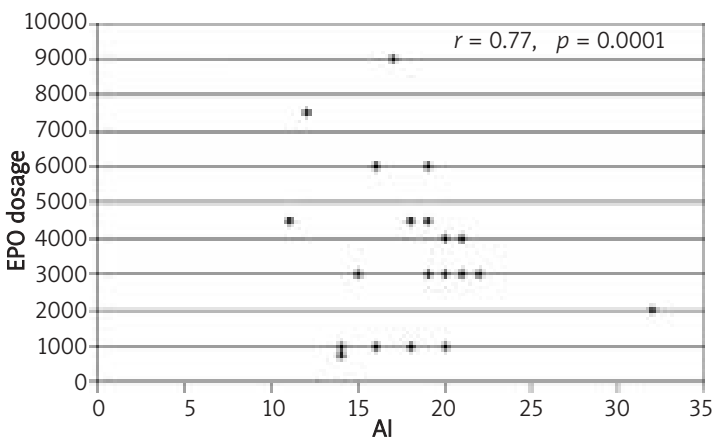

Figure 5. Scatter plot of EPO dosage vs. Al

different extents of protein binding [36]. The mechanism involving abnormal metabolism of trace metals has remained obscure.

Measurement of serum Al is made using an atomic absorption spectrophotometer. The normal range for serum $\mathrm{Al}$ as shown in this study $(<10 \mu \mathrm{g} / \mathrm{l})$ is in general agreement with other reports [26]. This study showed that patients on HD 


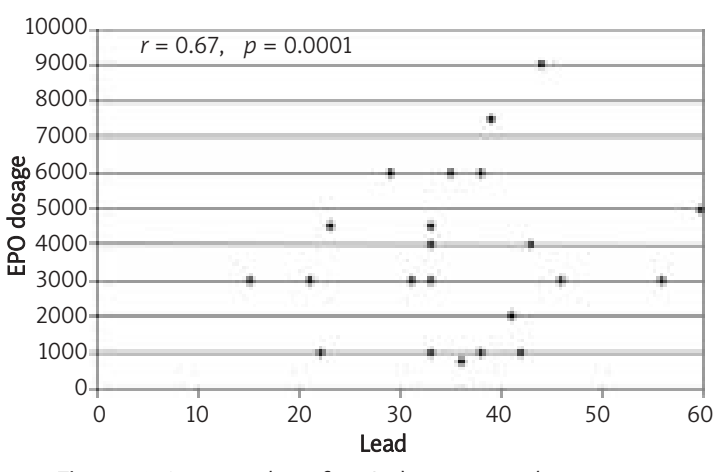

Figure 6. Scatter plot of EPO dosage vs. Pb

had elevated serum Al levels compared to normal controls. Although none of the patients on HD were on $\mathrm{AlOH}_{3}$ therapy, they had $\mathrm{Al}$ ranging up to $30 \mu \mathrm{g} / \mathrm{l}$, well above the normal range, but within the permissible non-toxic limits [31]. None of the patients had toxic levels of $\mathrm{Al}$ in the serum (>100 $\mu \mathrm{g} / \mathrm{l})$ [31]. Use of cooking utensils and food habits of the patients on HD were probably similar to the control subjects and such factors are unlikely therefore to explain the raised serum Al levels in the HD patients. The water source could have contributed to the elevated levels of serum Al in these patients [31]. Aluminium toxicity in uraemia is well documented. Absorption from acidic and inappropriately treated dialysis solutions is one of the major sources of Al toxicity [37]. Some researchers have found that Al will move into serum if the concentration in the dialysis solution is higher than $14 \mu \mathrm{g} / \mathrm{I}[36,37]$. At present, most Al comes from the diet, and more importantly from phosphate binders [37]. Aluminium intake from phosphate binders should be deliberately considered. Robertson [15] reported that older patients and those for longer duration ( $>5$ years) on $\mathrm{HD}$ are at a higher risk for Al toxicity.

In our results, the blood lead levels were significantly higher, almost thrice that of the control group in ESRD patients. Lead poisoning may remain asymptomatic for many years. Major forms of lead poisoning are lead colic, hypertension, and neuropathy. On the other hand, minor symptoms are common and variable: cramps, paraesthesia, intermittent pain in the limbs, chronic abdominal pain, and functional digestive disturbances. It is not easy to define these symptoms in patients with ESRD because uraemia itself may cause and/or aggravate these symptoms. Furthermore, chronic lead poisoning may be a cause of ESRD [38]. As the use of unleaded gasoline becomes more and more popular, and the use of $\mathrm{Pb}$ solder in canned food and plumbing is decreased, $\mathrm{Pb}$ levels are expected to decline gradually. The water used in dialysis may be the source of the elevated level of serum lead [39].
In this study, male patients on HD had a higher blood lead level than did females. This is in agreement with Rose et al. [35], who assumed that sex hormones altered the protein binding of trace elements during dialysis. However, the study done by Hsu et al. [40] on a larger sample size showed that females rather than males had higher levels of plasma copper, blood lead, and blood mercury. External sources may play a role in addition to sex hormone binding.

Interestingly, we noted a strong relationship between serum $\mathrm{Al}$ and serum Pb levels. This indicates that both of these elements may share some common absorption, transport, and tissue distribution pathways. To what extent their ionic radii might also play a role in this relationship is worth considering as well [40]. These findings may offer interesting perspectives for future studies.

In this study, serum lead accumulated with age, but not with dialysis duration. We hypothesize that age-dependent alteration in gastrointestinal (GI) absorption, or bone resorption, more so than haemodialysis itself, contributes to lead accumulation in haemodialysis patients. One hypothesis for such an event is that patients surviving longer may be exposed to an environment or diet with a high lead content [38]. Though plasma or whole blood levels of trace metals cannot represent their tissue accumulation [3, 17], Hsu et al. [40] showed that clinical manifestation of these metals correlates well with the plasma or blood concentration. Trace metal intoxication, such as by cadmium or aluminium, is likely responsible for refractory anaemia [40]; therefore, the source of contamination should be identified and removed. Possible routes of contamination in Taiwan are industrially polluted environments and diets, as well as medications such as herbal drugs [40].

In the present study, no correlations were found between TEs concentration and the duration of HD treatment. Hsieh et al. [41] found that the duration of HD did not affect the concentrations of TES except for nickel, which had a positive correlation with the HD duration. Also, Huang et al. [38] found that the concentrations of TEs were not affected by the duration of chronic ambulatory peritoneal dialysis (CAPD).

This study revealed a positive correlation between serum lead levels among HD patients and the dialyser surface area. Our finding is consistent with those of a previous report, in which lead was reabsorbed from the dialysis solution. D'Haese and De Broe [42] found that decreased renal excretion resulted in increased plasma TE levels in HD patients.

In this study a positive correlation was found between serum lead levels and serum albumin levels. A positive correlation between serum levels 
of lead and protein has been found in haemodialysed patients: that is, correlation of serum lead with total protein and prealbumin [41], and an increase in total protein and albumin during a haemodialysis session [40]. In uraemic children maintained on CAPD, a positive correlation was found between serum levels of lead and albumin [38]. In serum, lead is bound to circulating proteins, especially to a2-macroglobulin. Protein losses can diminish serum lead concentration. In proteinuric renal diseases, a negative correlation between serum lead level and urinary protein losses was observed, indicating that lead losses in urine were associated with protein losses [41].

The present study showed that serum parathyroid hormone levels positively correlated with the serum Al levels, thereby signifying more osteitis following maintenance haemodialysis, which potentiates aluminium deposition in bones and is a risk factor for osteitis fibrosa [43]. Aside from $\mathrm{Al}$, this study also showed a positive correlation between serum parathyroid hormone levels and serum lead levels. In previous studies, Douthat et al. [45] had reported that chronic renal failure or dialysis treatment per se does not lead to bone lead accumulation. In view of this and not withstanding that some pathology of lead on the skeleton has been hypothesized [44], increased bone lead concentrations most probably occur secondary to the presence of osteomalacia. Indeed, in contrast to an intact bone metabolism, removal of the element from this site by deposition of new material [45] occurs at a much lower rate in the presence of osteomalacia. We propose that ideally PTH levels should be maintained between $10 \mathrm{pmol} / \mathrm{l}$ $(100 \mathrm{pg} / \mathrm{ml})$ and $20 \mathrm{pg} / \mathrm{ml}$ to $30 \mathrm{pmol} / \mathrm{l}(200 \mathrm{pg} / \mathrm{ml}$ to $300 \mathrm{pg} / \mathrm{ml}$ ) in chronic dialysis patients, levels two to 4 times the upper limit of values found in normal subjects.

This study showed that the serum levels of both $\mathrm{Al}$ and $\mathrm{Pb}$ are positively correlated with the EPO dose taken by the patients. There was no relationship between the serum levels of TEs tested and any of the other medications that the HD patients were maintained on. Recombinant human erythropoietin (rHuEPO) has transformed the management of chronic renal failure and considerably improved the outcome of patients on regular chronic dialysis. However, a significant number of patients fail to respond to high doses of erythropoiesis-stimulating agents (ESAs) and several causes of inadequate response to epoetin therapy have been identified. Some factors, such as gender, age, length of time on dialysis, type of dialysis and co-morbidities such as haemoglobinopathy, are not susceptible to clinical intervention. However, many other factors can be adjusted. Iron deficiency is the most common factor that limits the response to
rHuEPO. Monitoring of iron parameters and a large use of iron supplementation result in an efficient epoetin response. Infection and inflammation have been shown to reduce responsiveness to ESAs by disrupting iron metabolism and increasing the release of pro-inflammatory cytokines that inhibit erythropoiesis. Increased dialysis dose is associated with improvements in anaemia correction and reduced requirements for ESAs. Severe hyperparathyroidism and aluminium overload lead to a reduced number of responsive erythroid progenitor cells [45]. Aluminium overload, like lead overload, does indeed depress haematopoiesis and has an inhibitory effect on several enzymes important in erythroid and iron metabolism in dialysis patients, but the severity of the anaemia and microcytosis depends on the degree of the aluminium overload $[45,46]$. Optimizing patient response to ESAs therefore requires consideration of many well-established factors and is important for both patient outcomes and cost of treatment.

There were some limitations in this study. The sample size of patients was small, as only one centre was included in the study. The design of our study does not enable us to discuss the role of lead overload in the onset of ESRD. Determination of such a relationship would require epidemiological studies conducted according to rigorous methodology. We cannot measure the bone aluminium content due to the invasive bone marrow aspirate and bone biopsy.

In conclusions, the levels of $\mathrm{Al}$ and $\mathrm{Pb}$ in blood samples of patients on dialysis were found to be higher than in the control group. Moreover, the study showed that analysing levels of $\mathrm{Al}$ and $\mathrm{Pb}$ may be useful in haemodialysis patients in evaluating TE status. The blood level of trace metals of these HD patients was not related to their medications except for the EPO dose. However, caution must be exercised in interpreting this result as dose and duration of medication, efficiency of HD and water treatment may play an important role. Otherwise, environmental factors, diet, and the aging process may contribute to the trace metal burden in uraemia. Al and $\mathrm{Pb}$ overload may be considered among the causes of inadequate response to epoetin therapy.

In conclusion, we would like to present the recommendations:

1. To prevent some complications in chronic HD patients, it is very important to regulate the levels of trace elements by adequate water treatment. Reverse osmosis is able to prevent the accumulation of the majority of trace elements in the patients. Correction of Al and Pb levels may help in optimizing patient response to epoetin therapy. 
2. Further investigations should be made to assess the possible sources of aluminium and lead that may lead to toxicity in such patients by analysing the dialysate fluid in order to identify the possible source of contamination.

3. Further study for determination of toxic metals in biological samples of human beings such as scalp hair samples is an important clinical screening procedure.

\section{References}

1. Kazi TG, Jalbani N, Kazi N, et al. Evaluation of toxic metals in blood and urine samples of chronic renal failure patients, before and after dialysis. Ren Fail 2008; 30: 737-45.

2. Skarupskiene I, Kuzminskis V, Abdrachmanovas O, et al. Influence of hemodialysis on changes of trace metals concentrations in blood of patients with end-stage renal failure. Medicina (Kaunas) 2003; 39 Suppl 1: 131-8.

3. Berlyne GM. Trace metal burden in uremia. In: Textbook of Nephrology. Massry SG, Glassock RJ (eds.), Baltimore: Williams \& Wilkins 1995; 1489-95.

4. Chazan JA, Lew NL, Loweri EG. Increased serum aluminium an independent risk factor for mortality in patients undergoing long-term hemodialysis. Arch Intern Med 1991; 151: 319-22.

5. Fenwick S, Roberts EA, Mahesh BS, Roberts NB. In endstage renal failure, does infection lead to elevated plasma aluminium and neurotoxicity: implications for monitoring. Ann Clin Biochem 2005; 42: 149-52.

6. Alfrey AC, LeGendre GR, Kaehny WD. The dialysis encephalopathysyndrome. Possible aluminum intoxication. N Engl J Med 1976; 294: 184-8.

7. Wanic-Kossowska M, Kazmierski M, Pawliczak E, Kobelski M. Combined therapy with L-carnitine and erythropoietin of anemia in chronic kidney failure patients undergoing hemodialysis. Pol Arch Med Wewn 2007; 117: 14-9.

8. Parsons V, Davies C, Goode C, et al. Aluminium in bone frompatients with renal failure. Br Med 1971; 4: 273-5.

9. Ellis HA, McCarthy JH, Herrington J. Bone aluminium inhaemodialysed patients and in rats injected with aluminium chloride: relationship to impaired bone mineralisation. J Clin Patho1979; 132: 832-44.

10. Elliott HL, Macdougall Al, Fell GS. Aluminium toxicity syndrome. Lancet 1978; 1: 1203.

11. Kaehny WD, Hegg AP, Alfrey AC. Gastrointestinal absorptionof aluminum from aluminum-containing antacids. N Engi J Med 1977; 296: 1389-90.

12. Cannata JB, Briggs JD, Junor BJR, et al. Effect of acute aluminium overload on calcium and parathyroid-hormone metabolism. Lancet 1983; 1: 501-3.

13. Van de Vyver FL, Van Waeleghem JP, De Broe ME, et al. Water treatment and dialysis dementia. Lancet 1982; 2: 1106.

14. Yacout MY, Naga SS, Risk AM, Al-Delgawi W, Yousef T. Study of the radiological manifestation of aluminium(Al) toxicity in long-trem hemodialysis patients. Abstract presented in the second congress of the Arab society of Nephrology and Renal Transplantation. Cairo 1991; 30.

15. Robertson WO. Chronic poisoning: Trace metal and others. In: Cecil's Textbook of Medicine. Goldman L, Bennett JC (eds.) W.B Saunders Co. 2000; 70-2.

16. Batschelet E, Brand L, Steiner A, et al. Kinetics of lead in the human on the body. J Math Biol 1979; 8: 15-23.
17. Robinowitz M, Wetherill G, Kopple J. Lead metabolism in the normal human: stable isotope studies. Science 1973; 182: 725-7.

18. Silbergeld EK, Schwartz J, Mahaffey K. Lead and osteoporosis: mobilization of lead from bone in postmenopausal women. Environ Res 1988; 47: 79-94.

19. Keller CA, Doherty RA. Bone lead mobilization in lactating mice and lead transfer to suckling offspring. Toxicol Appl Pharmacol 1980; 55: 220-8.

20. Llach F, Bover J. Renal osteodystrophies. In: Brenner and rector's the kidney. Brenner BM (ed.). W.B Saunders Co. 2000; 2103-66.

21. Hu H. Heavy metal poisoning. In: Harrison's principles of internal medicine. Fauci AS, et al. (eds.) McGraw-Hill Co. 1998; 2564-66.

22. Landrigan PJ. Strategies for epidemiologic studies of lead in bone in occupationally exposed populations. Environ Health Perspect 1991; 91: 81-6.

23. Kessler M, Durand PY, Hestin D, et al. Elevated body lead burden from drinking water in end-stage chronic lead failure. Nephrol Dial Transplant 1995; 10: 1648-53.

24. Van de Vyver FL, D'Haese PC, Visser WJ, et al. Bone lead in dialysis patients. Kidney Int 1988; 33: 601-7.

25. Kessler M, Durand PY, Hestin D, Gamberoni J, Chanliau J. Diagnosis and treatment of chronic lead poisoning in CAPD patients. Adv Perit Dial 1993; 9: 143-6.

26. D'Haese PC, Couttenye MM, Lamberts LV, et al. Aluminum, iron, lead, cadmium, copper, zinc, chromium, magnesium, strontium, and calcium content in bone of end-stage renal failure patients. Clin Chem 1999; 45: 1548-56.

27. American National Standards for Hemodialysis Systems. In: AAMI; Standards and Recommended Practices. Arlington, AAMI, 1990; 3: 35-54.

28. Maissonneuve SA (ed.). Water for diluting concentrated hemodialysis solutions; in European Pharmacopoeia, d 2. St. Ruffine, France, 1992, pt II, Fasc 16.

29. LeGendre GR, Alfrey AC. Measuring picogram amounts of aluminum and lead in biological tissue by flameless atomic absorption analysis of a chelate. Clin C/tern 1996; 22: 53-6.

30. Kao PC, GrantCS, Klee GG, Khosia S. Clinical performance of parathyroid hormone immunometric assays. Mayo Clin Proc 1992; 67: 637-45.

31. Taylor A (ed.). Guide to trace elements monitoring service, Guildford, 2006, $4^{\text {th }}$ ed.

32. Fenwick S, Roberts EA, Mahesh BS, Roberts NB. In endstage renal failure, does infection lead to elevated plasma aluminium and neurotoxicity? Implications for monitoring. Ann Clin Biochem 2005; 42: 149-52.

33. Bogden JD, Zadzielski E, Weiner B, Oleske JM, Aviv A. Release of some trace metals from disposable coils during hemodialysis. Am J Clin Nutr 1982; 36: 403-9.

34. Bustamante J, Martin Mateo MC, De Paula de Pedro A, Ortiz Manchado O. Changes in copper and ceruloplasmin in chronic renal insufficiency treated by hemodialysis and peritoneal dialysis. Nephron 1978; 22: 312-5.

35. Rose GA, Willden EG. Whole blood, red cell and plasma total and ultrafiltrable zinc levels in normal subjects and patients with chronic renal failure with and without hemodialysis. Br J Urol 1972; 44: 281-6.

36. Gidden H, Holland FF, Klein E. Trace metal protein binding in normal and dialyzed uremic serum. Trans Am Soc Artif Intern Organs 1980; 26: 133-8.

37. Huang JW, Hung KY, Lee SH, et al. Trace elements in blood and dialysate among continuous ambulatory peritoneal dialysis patients: a prospective, multicenter collaborative Study. Dial Transplant 2000; 29: 62-8. 
38. Lee SH, Huang JW, Hung KY, et al. Trace metals' abnormalities in hemodialysis patients: relationship with medications. Artif Organs 2000; 24: 841-4.

39. Yang JO, Lee EY, Hong SY. Influence of blood lead concentration on the nerve conduction velocity in patients with end-stage renal disease J Korean Med Sci 2006; 21: 290-4.

40. Hsu WA, Lee KC, Lin SL, et al. Clinical manifestations of trace metal abnormality in hemodialysis patients: a multicenter collaborative. Dial Transplant 1997; $26: 15$.

41. Hsieh YY, Shen WS, Lee LY, Wu TL, Ning HC, Sun CF. Longterm changes in trace elements in patients undergoing chronic hemodialysis. Biol Trace Elem Res 2006; 109: $115-21$.

42. D'Haese PC, De Broe ME. Adequacy of dialysis: trace elements in dialysis fluids. Nephrol Dial Transpl 1996; 11 (suppl 2).

43. Gal-Moscovici A, Popovtzer MM. New worldwide trends in presentation of renal osteodystrophy and its relationship to parathyroid hormone levels. Clin Nephrol 2005; 63: 284-9.

44. Douthat WG, Garay G, de Arteaga J, Fernández Martín JL, Cannata Andía JB, Massari PU. Biochemical and histological spectrum of renal osteodystrophy in Argentina. Nefrologia 2003; 23 Suppl 2: 47-51.

45. Jauréguy M, Choukroun G. Factors affecting the response to erythropoiesis-stimulating agents. Nephrol Ther 2006; 2 Suppl 4: S274-82.

46. Jabłonowski Z, Rysz J, Paradowski M, et al. The estimation of erythropoietin levels in the blood serum and cystic fluid in patients with solitary renal cysts. Arch Med Sci 2006; 2: 122-4. 